\title{
Translation Process Strategies: Psycholinguistic Aspects
}

\section{Стратегії в процесі письмового перекладу: психолінгвістичний аспект}

\section{Leonid Chernovaty}

DSc. in Pedagogy,

Full Professor

\author{
Леонід Черноватий \\ доктор педагогічних наук, \\ професор
}

E-mail: leonid.m.chernovaty@meta.ua http://orcid.org/0000-0003-3411-9408

\section{Natalia Kovalchuk}

Ph.D. in Pedagogy,

Associate Professor

\section{Наталя Ковальчук}

кандидат педагогічних наук, доцент

E-mail: kovalnatalya@,bigmir.net http://orcid.org/0000-0002-9483-4297

V.N. Karazin Kharkiv

National University

4, Svoboda Square, Kharkiv, Ukraine, 61022
Харківський національний університет імені В.Н. Каразіна

$\bowtie$ майдан Свободи, 4, Харків, Україна, 61022

Original manuscript received January 11, 2020

Revised manuscript accepted September 30, 2020

\section{ABSTRACT}

The aim of the paper deals with the preliminary verification of the hypothesis concerning the impact of the source text structure on the choice of translation strategy (form-oriented or sense-oriented) in the process of rendering a text in a native (Ukrainian) into a foreign (English) language by university students majoring in Translation.

The methods of the research included a comparative analysis of the target texts (English) translated (within a predetermined time limit) from the source text 
(Ukrainian) related to the domain of economics. The structure of the source text, while remaining grammatically acceptable in the Ukrainian language, had been deliberately made structurally non-congruent with that of the direct word order, which is most frequently used in English. The subjects, the fourth-year BA students majoring in Translation, whose command of English ranged between $B 2$ and C1 levels within the CEFR classification, had been properly motivated to achieve the maximum possible result. The analysis of the target texts was based on a number of parameters, which included the preservation of the source text information and its structure in them.

Results. It was established that in translating from a native into a foreign language, the subjects have a tendency to replicate the structure of the source text at the levels of clauses and sentences. However, it does not always result in the distortion of the source text sense or/and the violation of the target language norms as the subjects often managed to render the said sense and to keep to the said norms by means of changing the functions of the words in the sentence. The probability of the subjects' abandoning the source text structure increases when the latter is evidently unsuitable for replication, in which case they switch over to the sense-oriented strategy. The correlation of the two strategies in translating sentence segments is generally identical to the one related to clauses and sentences, while the form-oriented strategy generally prevails in rendering phrases.

Conclusions. The source text structure has a certain impact on the choice of translation strategy increasing the share of the form-oriented approach. However, this impact is not unequivocal and may depend on a number of factors, which require additional study. The paper outlines the prospects of further research.

Key words: interference, form-oriented strategy, sense-oriented strategy, source text, target text, translation, translation strategy, translation process.

\section{Introduction}

The translation process research is an essential instrument of its model development, which could provide a sound theoretical basis for the formulation of relevant hypotheses and their further testing. A substantial amount of research in this sphere focuses on the psycholinguistic aspects of the said process. The objects of research have included comprehension and memory mechanisms in translation and interpreting (Bajo et al., 2001), methods and problems of the translation process research (Lörscher, 2005; Dam-Jensen \& Heine, 2009; Göpferich \& Jääskeläinen, 2009; Martin, 2014), monitoring skills and self-awareness in the said process (Tirkkonen-Condit, 2005), a theoretical framework for situating translation expertise within empirical translation studies (Shreve, 2006), the correlation between the source 
and target texts parallel and sequential processing (Balling, Hvelplund \& Sjwrup, 2014), the role of metaphor in the translation process research (Schaffner \& Shuttleworth, 2015), micro and macro translation units of the said process (Alves \& Goncalves, 2015), evolution of its efficacy in the translation competence acquisition (PACTE, 2019), mechanisms of targeted translation nominations (Rebrii, 2012).

According to the available data (Lörscher, 2005; Tirkkonen-Condit, 2005; Balling, Hvelplund \& Sjwrup 2014), we may distinguish different translation strategies, depending on the approach to the source text (ST). The form-oriented strategy (literal translation) may cause a considerable source language (SL) interference, resulting in the violation of the target language (TL) norms in the target text (TT). The sense-oriented strategy involves rendering the ST meaning, abstracting from the ST structure. Professional translators take a predominantly sense-oriented approach (Lörscher, 2005). However, there is a considerable amount of findings (Lörscher, 2005; Tirkkonen-Condit, 2005; Balling, Hvelplund \& Sjwrup 2014) to believe that all future translators inevitably go through the stage of literal translation, which some view as a 'default translation strategy', raising its status to that of a 'translation universal' (Tirkkonen-Condit, 2005; Balling, Hvelplund \& Sjwrup 2014). Thus, the development of the professional translator's competence may be regarded as a gradual decrease of the literal translation operations share (though they remain available for the translator) accompanied by the parallel increase of the sense-oriented operations share in the translator's performance. However, the dynamics of this process has not been sufficiently researched and requires additional study to develop the translation psychological mechanisms model. It provides for the relevance of this paper.

Thus, our research is aimed at the preliminary study of the correlation between the form-oriented and sense-oriented strategies in the translation process to formulate the appropriate hypotheses and test them later at the different levels of translation competence development. The results, inter alia, may be taken into account in translator training. To achieve this aim, we had to complete a number of tasks: to select the subjects and the ST, organize its translation from a native (Ukrainian) into a foreign (English) language, carry out the TT analysis according to the pre-established criteria, compare the subjects' results, formulate preliminary conclusions, and outline the prospects of further research. 


\section{Methods}

The subjects. Nine fourth-year BA students majoring in Translation (two males and seven females) of the School of Foreign Languages at V.N. Karazin Kharkiv National University (Ukraine), 20 to 22 years of age, who studied English as their second foreign language (German being the first one). Their total amount of contact hours for learning English at university exceeded 800, without taking into account their related experience in the secondary school. Thus, within the CEFR classification (CEFR, 2018), the expected level of their command of English ranged from B2 to $\mathrm{C} 1$. Their experience in specialised translation (social-political and legal) amounted to 120 contact hours. The subjects were properly motivated as the results of their translation task (see further) were taken into account when assessing their progress within the specific module.

Source text. As the subjects were half-way through the course of translation in the domain of economics, and had just finished the module 'The Structure of Economy', they were asked to translate into English a properly oriented Ukrainian 157-word ST. It consisted of nine sentences: a compound, a complex, two extended and five complicated simple sentences. An extended simple sentence is viewed here as a syntactic structure containing, except the subject and the predicate, the secondary parts of the sentence, such as objects, attributes, modifiers, while a complicated simple sentence - as a structure with one syntactic basis (subject and predicate), which may be developed into a compound or complex sentence (Zahnitko \& Myronova, 2013). For example, a complicated simple sentence Some goods are considered more valuable, being more necessary in a certain period of time may be transformed into a complex sentence Some goods, which are more necessary in a certain period of time, are considered more valuable.

The word order in English and Ukrainian is partially congruent as both languages have the direct word order (subject-predicateobject). In case of congruence, the literal translation strategy would not affect (at least, essentially) the TT content correspondence to that of the ST. However, in case of incongruence, this strategy might result in the complete failure to render the said content. For example, in the sentence 'Поточна ринкова вартість пропонує зацікавленим сторонам ціну' (The current market value offers the interested parties 
a price), «вартість» (value) is the subject, and «ціну»» (price) - is an object. In Ukrainian, we may move the object into the initial position and the subject - into the final one ('ціну зацікавленим сторонам пропонуе поточна ринкова вартість'), without a significant change of the meaning, i.e. «вартість» (value) remains the subject and «uiнy» (price) - the object of the sentence. However, a similar transposition in English (a price offers interested parties the current market value) would result in a complete distortion of the ST meaning.

To establish the correlation between the form-oriented and sense-oriented strategies in the subjects' translations, we deliberately transformed the ST sentences structure making it incongruent with the canonical direct word order in the TL (English). If the TT word order is more or less congruent with the one in the ST, it would mean that the particular subject uses the form-oriented strategy (FOS). Conversely, if the subject transforms the ST structure to meet the TL norms in the TT, it would be considered a proof of the sense-oriented strategy (SOS). The degree of the ST and TT structure congruence may allow formulating the preliminary conclusions concerning the correlation between the subjects' strategies, both as a group and each subject individually. Basing on these theses, we suggested the following hypothesis: in translating from a native language into a foreign one, students majoring in Translation have a tendency to rely on the ST structure (the form-oriented strategy), which induces the SL structure interference resulting in the violations of the TL norms or/and distortion of the ST sense in the TT.

\section{Results and Discussion}

The generalized results of the research are presented in Table 1, while the discussion follows it.

Sentence 1 (Завдяки використанню ресурсів, тобто факторів виробництва, відбувається сочіально-економічний розвиток країни $\breve{u}$ зростає обсяг ВВП) is a compound structure with the prepositional (Завдяки використанню ресурсів) and conjunctional (тобто факторів виробництва) complications. The expected FOS-generated sentence (slashes show the sentence division into segments): Due to the use of resources, / i.e. factors of production, / happens the socioeconomic development of a country / and grows the amount of GDP. 
A possible SOS-generated sentence: The country's social and economic development, as well as its GDP growth, happens due to the use of resources, i.e. production factors. The latter sentence contains syntactic transformations, which require complex ST sense processing, identification of the main semantic components of the message (action, its subject and object) and positioning them according to the TL norms at the stage of the TT sentence syntactic scheme programming.

Table 1. The correlation (in \%) of the form-oriented (FOS) and sense-oriented strategies (SOS) in the process of specialised translation (Economics) from language $\mathrm{A}$ (Ukrainian) into language B (English). F - fragments of the sentences

\begin{tabular}{|c|c|c|c|c|c|c|c|c|c|c|c|c|c|c|}
\hline \multirow{2}{*}{$\begin{array}{l}\text { Sentence } \\
\text { number }\end{array}$} & \multicolumn{2}{|c|}{ Total } & \multicolumn{2}{|c|}{ F 1} & \multicolumn{2}{|c|}{ F 2} & \multicolumn{2}{|c|}{ F 3} & \multicolumn{2}{|c|}{ F 4} & \multicolumn{2}{|c|}{ F 5} & \multicolumn{2}{|c|}{ F 6} \\
\hline & FOS & SOS & FOS & SOS & FOS & SOS & FOS & SOS & FOS & SOS & FOS & SOS & FOS & SOS \\
\hline 1 & 89.0 & 11.0 & 89.0 & 11.0 & 89.0 & 11.0 & 67.0 & 33.0 & 22.0 & 78.0 & & & & \\
\hline 2 & 44.0 & 56.0 & 44.0 & 56.0 & 44.0 & 56.0 & & & & & & & & \\
\hline 3 & 44.0 & 56.0 & 44.0 & 56.0 & 100 & 0 & 56.0 & 44.0 & 100 & 0 & 56.0 & 44.0 & 22.0 & 78.0 \\
\hline 4 & 11.0 & 89.0 & 11.0 & 89.0 & 44.0 & 56.0 & 22.0 & 78.0 & 33.0 & 67.0 & & & & \\
\hline 5 & 67.0 & 33.0 & 33.0 & 67.0 & 0 & 100 & 100 & 0 & & & & & & \\
\hline 6 & 100 & 0 & 100 & 0 & 100 & 0 & 100 & 0 & & & & & & \\
\hline 7 & 89.0 & 11.0 & 89.0 & 11.0 & 100 & 0 & & & & & & & & \\
\hline 8 & 22.0 & 78.0 & 78.0 & 22.0 & 100 & 0 & 100 & 0 & 100 & 0 & & & & \\
\hline 9 & 89.0 & 11.0 & 100 & 0 & 100 & 0 & 100 & 0 & 100 & 0 & 22.0 & 78.0 & 67.0 & 33.0 \\
\hline Average & 62.0 & 38.0 & 65.0 & 35.0 & 75.0 & 25.0 & 78.0 & 22.0 & 71.0 & 29.0 & 39.0 & 61.0 & 45.0 & 55.0 \\
\hline $\begin{array}{c}\text { Average } \\
\text { FOS by } \\
\text { fragments }\end{array}$ & & & & & & & 62 & & & & & & & \\
\hline $\begin{array}{c}\text { Average } \\
\text { SOS by } \\
\text { fragments }\end{array}$ & & & & & & & 38 & & & & & & & \\
\hline
\end{tabular}

Only one version $(11.0 \%)$ reveals a predominantly sense oriented strategy: Socio-economic development of a country and increase in amount of GDP takes place through the usage of supplies, which are the factors of production (the subjects' versions are given in their original form, including the deviations from the TL norms).

Other subjects' strategies (89.0\%) were mostly based on replicating the ST structure. Segment 1 was rendered literally: Due to (the) use (using, usage) of resources (55.0\%); Thanks to the use (usage) of (the) resources $(22.0 \%)$; Owing to the using of supplies $(11.0 \%)$.

Segment 2 was replicated by almost all (89.0\%) subjects: (the) factors of production. Though this version is within the TL norms, none of the students used a suitable alternative (production factors), which required the transposition, and thus, a move from the form-oriented to 
the sense-oriented strategy. The exception was the version suggested by one subject (economic resources), though she slightly changed the ST meaning.

It was more difficult to replicate the segment 3 ST structure because, though it had the subject and the predicate (which should go in this very sequence in the TT), the predicate in the ST occupied the initial position, and it made some subjects try to preserve even such unnatural (for English) word order. Some students (33.0\%) attempted using there is structure: there is a (the) social and economic (socio-economic) development (growth) of the country. One subject (11.0\%) replicated the ST structure without any changes, which resulted in the TL norms violations (happens the socio-economic growth of the country). Another one $(11.0 \%)$ omitted the verb (the social-economic growth) causing the distortion of the ST sense, while the remaining subjects (33.0\%) resorted to transposition, moving the verb to the predicate position (at the end of the segment): the socio (social)-economic development (growth) of the country takes place (goes on, realizes). It is worth mentioning that all subjects preserved the final ST position of the lexeme 'країни' (of the country), though it would have been logical to use fronting (The country's social and economic development) to provide a closer connection between the subject and the predicate. It is but another evidence of the subjects' predominantly literal translation.

Finally, in segment 4, where the predicate is in the initial position once again, most of the subjects used transposition: and the volume (amount) of the GDP increases (is increasing). However, even in this case, they have been trying to get as close as possible to the ST word order. It is revealed in the attempts to fill the second position (occupied by the verb 'зростає' (grows) in the ST) with some word similar in the meaning though belonging to a different part of speech: and increasing of GDP takes place (11.0\%), and a growing mass of GDP (11.0\%) or and the increase of GDP (11.0\%). Another evidence of the formoriented strategy is an attempt to preserve the word 'обсяг' (volume) in the TT, though the context allowed omitting it without any loss of the ST sense, as it was done by $33.0 \%$ of the subjects (and the GDP grows (increases)). However, most of the students (56.0\%) replicated the ST phrase ('обсяг ВВП'): volume (mass, amount, output) of the GDP.

Sentence 2 (Обмеженими й такими, щуо мають кількісну та якісну визначеність, є усі виробничі ресурси будь-якої країни) has 
a complicated structure, where the subject ('виробничі ресурси') has been moved to the end of the sentence, the link-verb $(\epsilon)$ stands in front of the subject, and the remaining part of the complex nominative predicate ('обмеженими' and 'такими, щзо мають ... визначеність') is in the initial position. The expected FOS-generated sentence: Limited and such that have quantitative and qualitative definiteness are all production resources of any country. A possible SOS-generated sentence: In any country, all production resources are limited and have specific quantitative and qualitative characteristics. Like in the previous sentence, the generation of the TT with the direct word order requires a complex ST information processing and reorganization of its semantic components at the stage of the TT internal programming (Leontev, 1969; Steinberg, Nagata \& Aline, 2013; Zalevskaja, 2013).

Almost half of the subjects chose the form-oriented strategy ranging from the attempts of translating each word exactly in the ST order to some variations. An example of the first strategy in rendering segment 1 may be the case when the amount of words (nine) and their order in the ST and TT completely coincided: Limited and such that have quantitative and qualitative determinancy (subject 8). In other cases, there might have been more (The limited resources and which have quantitative and quality certainty - subject 5) or fewer (Limited and knowing the quantity and the quality definition - subject 3, Limited and quantity and quality measured - subject 6) words, but there is no doubt about the subjects' form-oriented strategy.

This is also true concerning the rendering of segment 2, where three subjects used literal translation (are all (the) productive (production) resources of any country), while one unsuccessfully attempted the application of there are structure: (and there are resources of any country). On the other hand, $56.0 \%$ of the subjects effectively applied the sense-oriented strategy concerning both segments by means of their transposition. Segment 1 was rendered in a relatively uniform manner (All (the) productive (production, industrial) resources (supplies) of any country are limited), while there was a greater variety concerning segment 2: and defined by quantity and quality; and have their quantitative and qualitative determinacy; and which have a quantity and quality distinctness; and definition in amount and quality; and with quantitative and qualitative definiteness. However, in all those cases, the subjects' sense-oriented strategy is evident. 
The complicated simple sentence 3 (До трудових факторів відносяться чисельність економічно активного населення, рівень його освіти (як загальной, так і професійної), ділової кваліфікацї, співвідношення зайнятих $і$ безробітних, можливості зміни галузевої i територіальної структури зайнятості, наявність систем підготовки $i$ перепідготовки фахівців) comprises a prepositional phrase at its beginning, and its six extended homogenous components. The expected FOS-generated sentence: To labour factors are related / the amount of economically active population, / the level of its education (as general, as and vocational), business qualification, / the ratio of the employed and unemployed, / possibilities of changing the sectoral and territorial structure of employment, / availability of the system for the training and retraining of specialists. A possible SOS-generated sentence: Labour factors include ... or one may expect fronting of all homogenous components to the initial position of the subject: The amount of economically active population... are related to labour factors. Other variants are reviewed below.

Though the transformation of the prepositional phrase into the subject-predicate one seems obvious, $44.0 \%$ of the subjects replicated the ST structure (To (the) labor factors refer (belong, are belonged, rank)), which resulted in the violation of the TL norms. The remaining subjects used transformations, confirming their sense-oriented strategy: the first (The labor factors include (are)) and the second (The number of economically active population... belong (refer) to the labor factors) transformation variants account for $22.0 \%$ each, and one subject $(11.0 \%)$ used a detached phrase (As to the working factors, they are...). The structure of the homogenous segments was mostly replicated, which was generally acceptable, taking into account their overall congruence in the two languages, though there were some transformations as well. Segments 2 and 4: total replication (the amount) of economically active population; the ratio of employed and unemployed people); segment 3: $56.0 \%$ - literal translation of the phrase 'рівень його освіти' (the level of its education); 44.0\% - transformations: $11.0 \%$ - acceptable deletion of the word 'üozo'(its) in the TT (the level of education), $11.0 \%$ substitution of its for their with transposition (their level of education), $11.0 \%$ - additional transposition with the conversion into a prepositional structure (their education level). 
Segment 5: 56.0\% - literal translation (opportunities to change the sectorial (industry, branch) and territorial structure (composition) of employment (job, occupation); 44.0\% - word transposition and deletion (changing the structure of employment according to branch and territory; opportunity to change the branch and the territorial structure; changing working sector and territorial employment structure; areal and territorial change of employment structure.

Segment 6: $22.0 \%$ - literal translation (availability (presence) of a system (systems) for training (qualification) and retraining (requalification) of specialists). In the remaining cases, the subjects applied transformations, which included word deletion (and even the systems of training and retraining), transposition (availability (existence) of training and retraining systems (training system and retraining) of specialists (experts, workers)), or a combination of transposition and deletion (existence of the training systems and the system of personnel development). The structure of the phrase 'системи підготовки $i$ перепідготовки', which is part of this segment, was replicated in $33.0 \%$ of the cases (systems of training and retraining).

Complicated simple sentence 4 (Важливими є також запаси корисних копалин, їхнє місие розташування, інфраструктурна облаштованість регіонів видобутку $i$ переробки, технологія видобутку) has a complex inverted predicate at the beginning of the sentence and a long subject group comprising five extended homogenous components. The expected FOS-generated sentence: Important are also / deposits of natural resources (minerals), / their place of location, / infrastructural arrangement of the areas of mining and processing, I technology of mining. A possible SOS-generated sentence: Other important factors include the amount of natural resources (minerals), their location, the availability of the corresponding infrastructure in the mining and processing areas, and the mining technology. Another possible variant involves fronting all the homogenous elements into the position of the subject with the direct-word order complex predicate completing the sentence (The amount of natural resources (minerals), their location... are also important).

Only one subject attempted replicating the general structure of the ST, leaving segment 1 at the beginning of the sentence and maintaining the sequence of its elements (Important is also...). We may also attribute here the variant suggested by another subject, who sustained 
the position of segment 1 but additionally used transposition (Also important are...). Other subjects used various types of transformations, which indicate the sense-oriented strategy. The first (Another important fact is...) and the second (The presence of natural resources... are important, too; Mineral resources... are very important, too) variants of the ST restructuring accounted for $22.0 \%$ each, while the rest combined both of them (Mineral supplies are also very important: where they are located...; Mineral reserves and their location are important...).

In rendering segment 2, only one subject completely replicated all ST words and their sequence (supplies of mineral, its place in the position). Three more subjects, while generally maintaining the ST structure, additionally used word deletion (reserves of minerals, their location; minerals, their location) or transposition (mineral reserves, their location).

The ST structure of segment 3 was completely replicated by $22.0 \%$ of the subjects (infrastructure, and equipment of (the) regions of their extraction (production) and processing (recycling)), while the rest applied addition (infrastructural equipment of the regions, where these resources are extracted and manufactured) and transposition (infrastructural equipment of (the) mining (manufacturing) (and) conversion (processing) districts (regions)).

The two strategies in translating segment 4 distributed in the following way: $33.0 \%$ replicated the ST structure (technology of extraction (production, mining)), while the remaining subjects applied transposition (extraction (production, mining, manufacture) technology).

The potential difficulty of rendering simple extended sentence 5 (Удосконалюванням технологї видобутку $i$ переробки частково можуть бути компенсовані кількісні обмеження розвіданих запасів) is related to the fact that its subject is in the final position (after the predicate), while the sentence begins with the object. The expected FOS-generated sentence: By improvement of technologies of mining and processing, / partially may be compensated / the quantitative limitations of the known deposits. A possible SOS-generated sentence: The quantitative limitations of the known deposits may be partially compensated by improving the mining and processing technologies.

In sentence 5, two subjects transposed segments 1 and 3 , and another one - segments 2 and 3 (By the improvement of the mining and conversion technology the quantitative limitations of explored reserves 
can be compensated). The rest (67.0\%) applied literal translation maintaining the segment sequence in the TT, but it did not always result in the ST sense distortion. For example, subject 1 transformed segment 1 into the subject of the sentence, changed the Passive Voice of the predicate verb into Active, having achieved the optimal expression of ST sense according to the TL norms: The improvement of technologies of extraction and processing can partially compensate for the quantitative limits of known resources. Subject 9 used a similar strategy with the similar outcome: Improvements in production and processing technology can partly offset the quantitative limitations of explored reserves. However, in other cases, the maintenance of the ST word order did result in the violations of the TL norms, as well as the ST sense dilution (The development of the mining technology can be used the compensated quantity restriction of explored supplies; As improvement of the production technology and recycling can be partly the compensated quantitative limits of explored supplies) or its complete distortion (The improving of producing technology and recycling can be partially compensated by quantitative limitation of extracted supplies).

The share of replicating the segment 1 (two students moved it into the final position) structure amounted to $33.0 \%$, the remaining subjects deleted the preposition by (the instrumental case marker), because they transformed this segment into the subject, which did not require any preposition, being in the nominative case.

In rendering segment 2, all subjects resorted to transposition (can partially), as in English, it is difficult to place an adverb in front of a modal verb.

Conversely, all students applied literal translation in rendering segment 3 (quantitative limits of known resources), because the principles of its structure in the two languages coincided.

The structure of complex sentence 6 (Основа будь-якого підприємства складається з виробничих фондів, щзо розглядаються як найактивніший чинник виробництва) allowed its replication without any essential TL norms violations (The basis of any enterprise / consists of production assets, / which are regarded as the most active factor of production). However, some transformations were possible as well, for example, fronting the phrase 'виробничі фонди' (production assets) into the subject's position: Production assets, the most active factor in this process, form the basis of any production enterprise. 
All subjects maintained the ST structure, both at the level of this sentence in general and its segments, in particular: segment 1 - The basis (base) of any enterprise (business, production); segment 2 - consists (is comprised) of the production (producing, industrial) fund(s); segment 3 which are considered as the most active factor of production. The clear evidence of the interlanguage interference is the use $(67.0 \%)$ of as in the TT, which is a literal translation of the corresponding lexeme in the ST, and is not its best counterpart in the TL. The remaining 33.0\% involved the more appropriate versions: considered to be the most active factor or considered the most active factor.

Structurally, simple extended sentence 7 (Вони характеризуються цілком визначеними якісними $i$ кількісними характеристиками) is relatively uncomplicated. The expected FOS-generated sentence: They are characterized / by quite definite qualitative and quantitative characteristics. A possible SOS-generated sentence: They possess definite qualitative and quantitative characteristics.

Quite predictably, $89.0 \%$ of the subjects completely replicated the ST structure, and only one used the phrase They have instead of They are characterized in segment 1 . In segment 2, all students applied literal translation maintaining the amount and the sequence of the ST items in the TT. One subject omitted the preposition by (denoting an instrumental case), which can also be explained by the SL interference, as there is no preposition in the ST, because cases in Ukrainian are marked by affixes.

Sentence 8: Сюди відносяться техніко-технологічний рівень основних фондів, вартість, вік $i$ зношеність, відповідність екологічним вимогам $i$ інші характеристики. The expected FOS-generated sentence: Here belong / the technical-technological level of basic (production) assets, / cost, age and wear, / conformity to (compliance with) ecological requirements and other characteristics. A possible SOS-generated sentence: They (characteristics) include the basic (production) assets' level of technology, their cost, age and wear, conformity to (compliance with) ecological requirements.

The complicated simple sentence 8, comprising four extended homogenous components, was translated almost exclusively by means of transformations. In rendering segment 1, 22.0\% of the subjects transformed the homogenous elements into the subject group of the sentence (The technical and technological level...), completing it with the predicate (belong here (to this)), and the rest - introduced a new 
grammatical subject (They (These) include (comprise)). However, the structure of other segments was replicated, sometimes with word additions: segment 2 - technical and technological level of basic (principle) funds (assets); segment 3 - cost (value), age and (degree of) wear (worn-out state, shabbiness, condition); segment 4 correspondence (accordance, compliance) to ecological standards (requirements) and other characteristics.

The simple complicated sentence 9 (Спеціальним фактором виробництва виступають інноваційні ресурси, а також ресурси управління, тобто кількість управлінських кадрів, ӥхній професійний рівень, досвід роботи, здатність до адаптації в нових умовах господарювання) comprises an inverted complex nominative predicate with a link-verb 'вистуnають' (constitute) and its nominative part, situated in front of it, and five extended complicated homogenous elements. The expected FOS-generated sentence: To the special factors of production belong / innovation resources, / and also resources of management, that is the amount of managerial staff, / their professional level, / experience of work, / ability to adapt to the new conditions of economics. A possible SOS-generated sentence: The innovation resources, as well as the managerial potential (the amount of managerial staff, their professionalism, experience and adaptability to the new economic environment) belong to the special factors of production.

Most subjects $(89.0 \%)$ replicated the structure of the sentence with only one of them applying the expected transformation (Innovations resource and management resources... are the special factor of production). This tendency dominates within each segment as well. In rendering segment 2, there were attempts both to get the TT structure closer to that of the ST, even violating the TL norms (As the special factor of production, can be seen...), and to adapt it (without changing the ST word order) to the said norms, transforming the ST nominative part of the complex predicate into the subject of the sentence, changing the link-verb ((The) special factors of production are...) or substituting it with a full-meaning verb (The special factors of production include (are represented by)).

Thus, in rendering this sentence, the two antagonistic strategies merge into a single one, when the word order in the two texts is formally congruent, while their syntactic functions change. 
Segment 2 was generally replicated with the exception of the phrase 'ресурси управління', where all subjects applied transposition (management resources). Most subjects (56.0\%) preserved all ST words and replicated their order in the TT (except the said phrase), e.g. innovative resources (and) as well as (also, like) management (managerial) resources. The remaining subjects omitted the word 'також' (also), e.g. innovative resources and management resources.

The structure of segment 3 was completely replicated (i. e. the quantity (number, amount) of managing (management, managerial) personnel (workers, staff)), as well as that of segment 4 (their professional (skills) level), while in segment 5 the share of replication amounts only to $22.0 \%$ (experience of work, experience in profession); the remaining cases are accounted for by word deletion - $11.0 \%$ (experience) and transposition - $(67.0 \%)$ (job (work, working) experience). In rendering segment 6, most subjects $(67.0 \%)$ used literal translation (ability to adapt (themselves) to new conditions of production (management, economy)), while others resorted to transposition to translate the phrase 'умови господарювання': есопотіс conditions (terms).

\section{Conclusions}

Our research has partially confirmed the hypothesis concerning the future translators' inclination to subconsciously rely on the ST structure (the form-oriented strategy), boosting the share of literal translation. As a result, the subjects tend to mostly $(62.0 \%)$ replicate the structure of clauses and sentences in the TT. However, the extreme form of literal translation, i.e. the one, which involves the 'mechanical exchange of language signs' and 'prevents any checking on the sense of the TL text' (Lörscher, 2005: 598) is seldom seen at the subjects' level of communicative and translation competence development. In most cases, even when they resort to literal translation, it causes only deviations from the TL norms, as the subjects mostly manage to preserve the ST sense by changing the functions of the words in the sentence. The probability of the subjects' abandoning the ST structure increases when the latter is evidently unsuitable for the replication, in which case they switch over to transformations (the sense-oriented strategy) (38.0\%). The correlation of the two strategies in translating sentence segments is generally 
identical to the one related to clauses and sentences $-62.0 \%$ versus $38.0 \%$ in favour of the form-oriented strategy. However, the parameter dispersion is narrower here, compare: the form-oriented strategy at the level of clauses and sentences - from $11.0 \%$ to $100.0 \%$, and at the level of sentence segments - from 39.0\% до 78.0\%; the sense-oriented strategy at the level of clauses and sentences - from $0 \%$ to $89.0 \%$, and at the level of sentence segments - from $29.0 \%$ до $61.0 \%$. On the level of phrases, the form-oriented strategy generally prevails. In particular, it is, manifested in the subjects' avoidance of attributive prepositional constructions, typical for English. Instead, the preference is given to the of-constructions (the literal translation of the genitive case in Ukrainian), though almost all subjects used some frequent economic collocations in the attributive prepositional form. Our research may also be regarded as an argument in favour of the assumption concerning the development of translator's competence as a process of gradual replacement of literal translation operations with the sense-oriented ones. The senseoriented operations share in the translation of the highest-scoring subject amounted to $78.0 \%$, while the similar share of the lowest-scoring one constituted a mere $11.0 \%$. It may be explained by a higher degree of parallel efforts cumulation, which the students with lower level of communicative and translation competence require to solve translation problems. This assumption requires a separate investigation, which is one of the prospects of our further research.

\section{References}

Zahnitko, A., \& Myronova, H. (2013). Syntaksys ukrainskoi movy. Teoretykoprykladnyi aspekt [Syntax of the Ukrainian Language. Theoretical and Applied Aspects]. Brno : Masarykova univerzita [in Ukrainian].

Zalevskaja, A.A. (2013). Voprosy teorii dvujazychija [Issues in the Theory of Bilingualism]. Moscow : Direkt-Media [in Russian].

Leontev, A.A. (1969). Psiholingvisticheskie edinicy $i$ porozhdenie rechevogo vyskazyvanija [Psycholinguistic Units and Speech Utterance Generation]. Moscow: Nauka [in Russian]

Rebrii, O.V. (2012). Suchasni kontseptsii tvorchosti u perekladi [Modern concepts of creativity in translation]. Kharkiv: KhNU im. V.N. Karazina [in Ukrainian].

Alves, F., \& Goncalves, J.L. (2015). Investigating the conceptual-procedural distinction in the translation process. In M. Ehrensberger-Dow, S. Gupferich \& S. O'Brien (Eds.), A relevance-theoretic analysis of micro and macro translation units. Interdisciplinarity in Translation and Interpreting Process Research (pp. 109126). Amsterdam: John Benjamins B.V. https://doi.org/10.1075/bct.72.09alv 
Bajo, T., Padilla, P., Muñoz, R. et al. (2001). Comprehension and memory processes in translation and interpreting. Quaderns. Revista de traducció, 6, 27-31.

Balling, L.W., Hvelplund, K.T., \& Sjwrup, A.C. (2014). Evidence of Parallel Processing During Translation. Meta, 59(2), 234-259. https://doi.org/10.7202/1027474ar

CEFR: The Common European Framework of Reference for Languages: Learning, Teaching, Assessment. Companion volume with new descriptors. (2018). Cambridge: Cambridge University Press.

Dam-Jensen, H., \& Heine, C. (2009). Process Research Methods and their Application in the Didactics of Text Production and Translation. Trans-kom, 2(1), 1-25.

Göpferich, S., \& Jääskeläinen, R. (2009). Process research into the development of translation competence: where are we, and where do we need to go? Across Languages and Cultures, 10(2), 169-191. https://doi.org/10.1556/Acr.10.2009.2.1

Lörscher, W. (2005). The Translation Process: Methods and Problems of its Investigation. Meta, 50(2), 597-608. https://doi.org/10.7202/011003ar

Martin, R.M. (2014). A blurred snapshot of advances in translation process research. MonTI Special Issue - Minding Translation, 49-84.

PACTE Group. (2019). Evolution of the Efficacy of the Translation Process in Translation Competence Acquisition. Meta, 64(1), 242-265. https://doi. org/10.7202/1065336ar

Schaffner, Ch., \& Shuttleworth, M. (2015). Metaphor in translation: Possibilities for process research. In M. Ehrensberger-Dow, S. Gupferich \& S. O’Brien (Eds.), A relevance-theoretic analysis of micro and macro translation units. Interdisciplinarity in Translation and Interpreting Process Research (pp. 95-108). Amsterdam: John Benjamins B.V. https://doi.org/10.1075/bct.72.08shu

Shreve, G.M. (2006). The Deliberate Practice: Translation and Expertise. Journal of Translation Studies, 9(1), 27-42.

Steinberg, D.D., Nagata, H., \& Aline, D.P. (2013). Psycholinguistics: language, mind and world. New York: Routledge. https://doi.org/10.1075/bct.72.08shu

Tirkkonen-Condit, S. (2005). The Monitor Model Revisited: Evidence from Process Research. Meta, 50(2), 405-414. https://doi.org/10.7202/010990ar

\begin{abstract}
АНОТАЦІЯ
Метою роботи є попередня перевірка гіпотези про вплив структури тексту оригіналу на вибір стратегії перекладу (смислової чи послівної) студентами, що спеціалізуються у срері міжмовного посередництва, в процесі письмової медіації з рідної (української) мови на іноземну (англійську).

Методика дослідження включала порівняльний аналіз передачі англійською мовою українськомовного галузевого тексту у сфері економіки у формі письмового перекладу з обмеженням часу. Структуру згаданого тексту (в межах норм української мови) було трансформовано, максимально віддаливши її від прямого порядку слів, характерного для англійської мови. Випробуваних, студентів четвертого курсу бакалаврату (спеціалізація «Переклад»), рівень володіння англійською мовою яких коливалася між рівнями В2+ ma C1, було належним чином мотивовано на досягнення максимального результату. Параметри аналізу тексту перекладу включали ступінь збереження змісту $i$ структури тексту оригіналу випробуваними.
\end{abstract}


Результати аналізу засвідчили, що в процесі письмового перекладу з рідної мови на іноземну випробувані мають тенденцію переважно дотримуватись структури тексту оригіналу на рівнях простого й складного речень. Однак ие не завжди спричинює викривлення смислу тексту оригіналу та/або відхилення від норм мови перекладу в тексту перекладу, оскільки, випробуваним нерідко вдається передати згаданий смисл та/або дотримуватись згаданих норм за рахунок зміни функцій слів у реченні. Відхід від структури тексту оригіналу $\epsilon$ найбільш вірогідним у ситуаціях, коли вона $\epsilon$ очевидно непридатною для копіювання, внаслідок чого спостерігається переключення на стратегію смислового перекладу. Співвідношення двох стратегій при перекладі фрагментів $\epsilon$ ідентичним тому, що зафіксовано для речень, а на рівні словосполучень спостерігається загальна тенденція до послівного перекладу.

Висновки. Структура тексту оригіналу впливає на вибір стратегії перекладу, збільшуючи частку послівного перекладу, однак такий вплив не є однозначним, і може залежати від певних факторів, які потребують додаткового вивчення. Окреслено перспективи подальшого дослідження.

Ключові слова: інтерференція, письмовий переклад, послівний переклад, прочес перекладу, смисловий переклад, стратегія перекладу, текст оригіналу, текст перекладу.

\section{Черноватый Леонид \& Ковальчук Наталья. Стратегии в процессе письменного перевода: психолингвистический аспект}

\section{АННОТАЦИЯ}

Целью работы является предварительная проверка гипотезы о влиянии структуры текста оригинала на выбор стратегии перевода (пословной или смысловой) студентами, которые специализируются в сфере межъязыкового посредничества в процессе письменной медиации с родного (украинского) языка на иностранный (английский).

Методы исследования включали сравнительный анализ передачи на английском языке украиноязычного текста в области экономики в форме письменного перевода с ограничением времени. Структура упомянутого текста (в рамках норм украинского языка) была трансформирована, максимально удалив ее от прямого порядка слов, характерного для английского языка. Испытуемые, студенты четвертого курса бакалаврата (специализация «Перевод»), уровень владения английским языком которыми колеблется межу уровнями В2+ и C1, были надлежащим образом мотивированы на достижение максимального результата. Параметры оценивания текста перевода включали степень сохранения содержания и структуры текста оригинала в текстах перевода.

Результаты анализа свидетельствуют, что в прочессе письменного перевода с родного на иностранный язык испытуемые имеют тенденцию преимущественно придерживаться структуры текста оригинала на уровнях простого и сложного предложений. Однако это не всегда приводит к искажению смысла текста оригинала и/или отклонению от норм языка 
перевода в тексте перевода, поскольку испытуемым часто удается передать упомянутый смысл за счет изменения функций слов в предложении. Отход от структуры текста оригинала наиболее вероятен в случаях, когда она оказывается очевидно непригодной для копирования, вследствие чего наблюдается переключение на стратегию смыслового перевода. Соотношений двух стратегий при переводе фрагментов является идентичным тому, которое зафиксировано в случае предложений, а на уровне словосочетаний наблюдается общая тенденция к пословному переводу.

Выводы. Структура текста оригинала влияет на выбор стратегии перевода, увеличивая удельный вес пословного перевода, однако такое влияние не является однозначным и зависит от некоторых факторов, которые требуют дополнительного изучения. Очерчены перспективы дальнейших исследований.

Ключевые слова: интерференция, письменный перевод, пословный перевод, процесс перевода, смысловой перевод, стратегия перевода, текст оригинала, текст перевода. 